\title{
Towards a History of Files
}

\section{MATTHEW S. HULL, STEFAN NELLEN, THOMAS ROHRINGER}

That a journal dealing with the history of public administration engages with files may seem obvious but it is by no means self-evident. Max Weber famously observed that the modern office is based upon "files" in his posthumously published "Wirtschaft und Gesellschaft«: »The management of the modern office is based on written documents (the sfiles`), which are preserved in their original or draft form, and upon a staff of subaltern officials and scribes of all sorts «. ${ }^{1} \mathrm{He}$ also pointed out that in >modern administrative spaces, the sbureau arose only from this constellation of personnel and artefacts: "The body of officials working in an agency together with the respective apparatus of material implements and the files makes up a bureau (in private enterprises often called the sthe counting house , Kontor) « $^{2}$

Shortly after Max Weber had identified files as a core element of bureaucracies for processing knowledge, they also became proper objects of scientific study. With his 1935 book "Aktenkunde. Ein Handbuch für Archivbenutzer mit besonderer Berücksichtigung von Brandenburg Preußen« [The Study of Files. A Handbook for Users of Archives Particularly Considering Brandenburg Prussia], the historian and archivalist Heinrich Otto Meisner elevated files to the status of a research object for archival science. He was the first to dedicate a whole book to the study of files, thereby revolutionizing archival science. Until then, the auxiliary sciences of history had been dominated by the study of - primarily medieval - charters. Meisner's handbook originated in lectures he had held at the Prussian Institute of Archival Science in Berlin. His students - mostly trained historians - appreciated the revolutionary implications of Meisner's undertaking, which opened up a new and innovative field of study:

\begin{abstract}
The actual object of study, the individual document, will be considered from three points of view: systematically, regarding its belonging to a specific stylistic form of document, analytically regarding its sinner ‘ and >outer characteristics and finally genetically regarding its development and life course as per the three zones chancellery, registry, and archive. ${ }^{3}$
\end{abstract}

This classification of a systematic, analytic and genetic study of files is still valid today. From the start, »The Study of Files « not only opens up an historical perspective on administrative bodies by considering the three semiotopes chancellery, registry and archive but also gives relevance to the material-technical dimensions of files through the analytic study of their souter features. In his contribution developing "a historical anthropology of bureaucracy«, Mario Wimmer traces Meisner's intellectual practice: For years, the historian- 
archivalist expanded and revised his manuscript of "The Study of Files" - shot through with empty pages - with annotation. Wimmer draws parallels between this intellectual-bureaucratic practice of revising and Meisner's historical revisionism.

Since Meisner's work, the study of files is an integral part of the auxiliary sciences of history. ${ }^{4}$ Through this method, generations of historians have learned to read, analyze and interpret archival sources. Despite the interest in files from sociologists and archival scientists, it took almost 70 years until historians in general (with exceptions like Michael Clanchy) ${ }^{5}$ and historians of public administrations in particular began to sdiscover ' files as a proper object of study and to take seriously their materiality. Although researchers used files for their analyses, they were more interested in what was inscribed on them than in their materialities and functions. As Ben Kafka put it, they were »looking through paperwork, but seldom paused to look at it« ${ }^{6}$ To a certain extent, this is part of its use as carrier of information. To fulfill their function as media, files in the broadest sense should not draw attention to their materiality and formal characteristics but to what was inscribed on them. Drawing from the study of discourse, materiality, cultural techniques as well as science and technology, scholarship on bureaucracy increasingly examines the role of documentation processes in the life of institutions. In his seminal 1986 essay »Visualization and Cognition. Thinking with Eyes", Bruno Latour pointed to the manifest agency of "the most despised of all ethnographic objects: the file or the record«:

The srationalization granted to bureaucracy since Hegel and Weber has been attributed by mistake to the smind of (Prussian) bureaucrats. It is all in the files themselves. [...] The scracy of bureaucracy is mysterious and hard to study, but the sureaur is something that can be empirically studied, and which explains, because of its structure, why some power is given to an average mind just by looking at files: domains which are far apart become literally inches apart; domains which are convoluted and hidden, become flat; thousands of occurrences can be looked at synoptically. More importantly, once files start being gathered [...] they can be arrayed in cascade: files of files can be generated and this process can be continued until a few men consider millions as if they were in the palms of their hands. ${ }^{7}$

In his 2002 ethnography of the Conseil d'État, the French administrative court, Latour has demonstrated how jurists make law with files. Latour shows how the administrative court deals with two types of documents: court records and legal texts:

The first are scattered and are put flat in a yellow folder, while the others are bound - and arranged vertically - with a cover of leather, imitation or real. The entire work consists of establishing the relation between these two collections of writings. [...] Between these two corpuses lies a multitude of photocopies, drafts, attempts and copies of Codes which allow the reporter to visually superimpose (but through which operation of recognition?) the documents included in one pile onto those included in the other. ${ }^{8}$

Through superimposition, a judge can connect these two corpora on an intertextual level. He drafts a report by creating relations between the elements of a case (concepts, arguments, documents), i.e. the file, and the elements of normative legal texts, thereby drawing them together. This eventually enables him to make a decision and dismiss or admit a claim, to render a verdict. Law is, therefore, created by "building a fragile bridge of texts $:^{9}$

The bridge has now been established by fitting elements of the claim into the texts and by weaving the means* by bringing them closer and closer to laws and decrees. To draw out the metaphor of the bridge: something is now going to be able to pass from one side to the other. Either in one direction, and this is annulment, or in the other, and that is rejection. ${ }^{10}$

As Latour defines the emergence of a judicial verdict as "a movement of interconnection of a specific case with a corpus of texts «, ${ }^{11}$ the file is nothing else than the medium, the materiality, which processes this verdict. From this perspective, recording and documenting constitute »epistemic practices «, ${ }^{12}$ which, however, attain their institutional and inter-institutional relevance through being purposefully retrievable. »[B]ureaucracies«, as 
Lisa Gitelman argues drawing on Matthew Hull's study of document practices in Islamabad, "don't so much deploy documents as they are partly constructed by and out of them «. ${ }^{13}$

Even before Latour explored the "Making of the Law«, jurist Cornelia Vismann reinvigorated the research on files in the fields of history, social sciences and cultural studies. In her seminal study »Files. Law and Media Technology«, first published in German in 2000, she analyzed the development of law from the perspective of bureaucracy and media technologies. In it, Vismann not only provided the study of files with a new theoretical basis but also wrote a history of files from antiquity (the Imperium Romanum) to the present (the >disappearance Thereby she broadens the historical study of files by more than 1300 years, simultaneously approaching the auxiliary sciences of history with the theoretical and methodological tools of media studies. As Felix Lüttge in his >Re-reading، essay explains:

The files in 'Files, elude any general definition. They are not sdiscrete and enumerable units‘, they are not the contents of manila folders and filing cabinets. The files, of which Vismann writes, scan appear in all shapes and forms: as loose pages, lying in little boxes, wrapped in packing paper, or enclosed in capsules; they may present themselves as bundles tied with a string or assume the shape of vertical folders ready to enfold anything that can fit between two paper covers ${ }^{14}$

The rich variety of material forms and effects of files described in the articles of this volume are evidence to support this point. However, we think our understanding of files is productively oriented by two key functions, closely linked to the material forms of files.

First, files materially and discursively compile every other kind of records and sometimes even other files in a temporally open manner. They are defined by their relation to other records - they gather, organize, articulate and store them. Understanding files as artefacts allows for an analysis of the historically specific ways through which documents are physically and discursively interrelated. Although many kinds of records, for example, land registries or voter lists, compile information, files are assemblages of other documents. Files are a material form of selection, a material synthesis of the documentary manifold and the basis for the intellectual judgements highlighted in Weber's account of the work of officials. Files materially and discursively recontextualize the other graphic artefacts they contain. Just as an utterance changes its significance with its semiotic context, the meanings of letters, reports, confessions, and maps are transformed when they are placed in files. Files transmute diverse documents into cases and bureaucratic objects. At the same time, unlike other kinds of documents, whose completeness and temporal finality are essential to their function, files grow and expand unlimitedly. With the perdurance of the sopen ‘ file, discourse within and with respect to a file is never brought to a point at which its significance is finally fixed and not subject to revision. ${ }^{15}$

Second, just as files bring documents together, they connect the activities of individuals and organizations in the simultaneous fabrication of an administrative act and an administrative agent. Records, like the buildings that house organizations, are a central component of what Weber called the "means of administration «. ${ }^{16}$ Organizations and organizational divisions are defined in part by the collections of records they authoritatively generate and control.

However, the circulation of a file, the activation of a subset of records in the process of an administration action, constructs in concrete forms the effective administrative agent it appears to presume. As Matthew Hull observed:

signs of a file's history are continuously and deliberately inscribed upon the artifact itself. In fact, such signs largely constitute the file, a peculiarity that gives it an event-like quality. A file is a chronicle of its own production, a sedimentation of its own history ${ }^{17}$

Its administrative inscriptions are simultaneously act and documentation: "Every file note indirectly contains a command. Reporting the execution of an order triggers the next one. [...] An executed command, then, has a double orientation: it generates the next command and notes its own execution ${ }^{18}$. What constitutes files are the "non-syntactical signs or operators [like $M$, coll, and repr] that send records into administrative orbit «: ${ }^{19}$ 
As algorithmic entities, files are after all not indebted to any author for their existence. Unlike books and other written documents, files are, in the terminology of archival sciences, , process-generated .20

The files "act as instruments to cohere and control the organization $\aleph^{21}$ or to connect different organizations. As Katherine Verdery ${ }^{22}$ showed in the case of the state socialist Romanian secret police, files can sometimes be the only ligament holding together segregated parts of an administrative process, linking people who must never meet. In the words of an archival scientist, "'[a] fter having fulfilled their control function, notes and underwritings become [...] an automatically generated protocol «, ${ }^{23}$ and in Vismann's own words, "the file contains its own progression «. ${ }^{24}$ However, Vismann does not analyze files only as a microphysics of power but aims at the big picture and its basis, as Lüttge elaborates:

With Derrida she speaks of a grammatology of files that does not analyze the content, but the mediality, materiality and functionality of files together with acts of transferring, recording and rescinding. These do not only constitute the history of law, but also played a part in the formation of those entities that form the basis of the law: truth, state and subject. Not files and their content in one office or the other concern Vismann, but the part that official records have in the emergence of the notions of truth, the concepts of state, and the constructions of the subject in Western history.${ }^{25}$

In an almost tragic irony of history, Lüttge observes that while the juristic Ph.D. thesis became a standard work in cultural and media studies, the history of law believes it can get along without files. ${ }^{26} \mathrm{He}$ contextualizes Vismann's study in the media-technology theories, but he goes further and sketches possible avenues for developing it further by pointing towards the history of users and a history of dysfunctions. In the same vein, we would argue that the degree to which files are faithful instruments of formal administrative control and organizational coherence has been exaggerated. Unlike large collections of records whose mass material immobility keeps them firmly associated with an administrative organization, files, to be useful, must move. When they move along their prescribed paths, they reinforce the normative organizational order, and the administrative agent they constitute coincides with the formal structure of the organization. However, the paths of files can diverge from the norm and can virtually reconstitute the roles of functionaries in decisions, remaking in unpredictable ways relations of hierarchy and the de facto makeup of the administrative agency of any particular act. ${ }^{27}$ JM Chris Chang's contribution describing the movement of a file on an accused adulterer in Maoist China, between the office of his work unit and the municipal authority of the woman he was engaged with, shows how the transfer of files linked bureaucratic processes unconnected by formal lines of authority.

In her contribution, Mariana Dias Paes takes up the issues Vismann had raised, arguing that historians of law should pay more attention to legal files. By analyzing documents from the Benguela District Court, she demonstrates how the materialities and formalities of court documents shaped the Portuguese Empire's colonial administration in the $19^{\text {th }}$ century.

Following Vismann, media studies engaged with the emergence of files. The media historian Bernhard Siegert shifts the focus of the auxiliary sciences of history towards cultural techniques by surveying files not so much for their content as "testimony of an historical reality of whatever kind «, but as »testimony to the practices and cultural techniques they represent in themselves «. ${ }^{28}$ Siegert reveals that premodern administrations were reliant upon writing materials cheaper than parchment to control the ever-changing streams of data, goods and people through the social practice of double-entry accounting. This created »a new form of documents [...] made from paper and relieved of the expectation sthat their validity would survive the course of time «: files. ${ }^{29}$

This phenomenon, the transition from the rage of charters s to the sage of files is the subject of Johannes Kaska's and Samuel Nussbaum's contribution. By analyzing two Austrian monasteries' administration strategies, Kaska and Nussbaum demonstrate how administrative forms and practices of recording and storing information were highly responsive to local conditions and challenges. The struggle to organize, communicate, store and retrieve knowledge lies at the heart of the contribution by Michael Moss and David Thomas, who deal with the development of the sfiler 
in the British administration from the early modern period to the $21^{\text {st }}$ century. In his contribution about late $19^{\text {th }}$ century business practices, Craig Robertson argues that a new form of storing files, the filing cabinet, fostered a new conception of information as a discrete unit. Kirsten Rüther in her contribution engages with the institution of the archive and how its personal and material dimensions shape research questions. Verne Harris and Shadrack Katuu in turn elucidate the role research played in the institutional formation and transformation of Nelson Mandela's archive.

Paying close attention to formal structures and materialities of written records, therefore, does not mean that the textual level will be dismissed; rather, it entails the analysis of the relationships between the forms of documents and the kinds of texts that are inscribed on them. Materials and forms influence what can be written and transmitted through them and whether they are recognized as struthful records or evidence. 
1. Max Weber: Economy and Society. An Outline of Interpretative Sociology, Berkeley / Los Angeles / London 1978, p. 957.

2. Weber: Economy and Society, p. 957.

3. Heinrich Otto Meisner: Aktenkunde. Ein Handbuch für Archivbenutzer mit besonderer Berücksichtigung BrandenburgPreußens, Berlin 1935, p. 3.

4. Michael Hochedlinger: Aktenkunde. Urkunden- und Aktenlehre der Neuzeit, Wien 2009.

5. Michael Clanchy: From Memory to Written Record 1066-1300, Cambridge 1979.

6. Ben Kafka: Paperwork. The State of the Discipline, in: Book History 12 (2009), pp. 340-353, at p. 341.

7. Bruno Latour: Visualization and Cognition. Drawing Things Together, in: Knowledge and Society. Studies in the Sociology of Culture Past and Present 6 (1986), pp. 1-40, at p. 26.

8. Bruno Latour: The Making of Law. An Ethnography of the Conseil d'État, Cambridge 2010, pp. 71 f.

9. Latour: Making of Law, p. 70.

10. Latour: Making of Law, p. 74.

11. Latour: Making of Law, p. 191.

12. Lisa Gitelman: Paper Knowledge. Toward a Media History of Documents, Durham / London 2014, p. 1.

13. Gitelman: Paper Knowledge, p. 5.

14. Felix Lüttge: Wieder gelesen: Cornelia Vismann, „Akten« (2000), in: Administory 4 (2019), pp. 176-182, at p. 177; quotes are taken from: Cornelia Vismann: Files. Law and Media Technology, Stanford 2008, p. xi.

15. Mikhail Bakhtin: Speech Genres, and Other Late Essays, translated by Vern W. McGee, ed. by Caryl Emerson / Michael Holquist, Austin 1986, p. 76.

16. Weber: Economy and Society, p. 980.

17. Matthew S. Hull: The File. Agency, Authority, and Autography in an Islamabad Bureaucracy, in: Language and Communication 23/3-4 (2003), pp. 287-314, at p. 296.

18. Vismann: Files, p. 8.

19. Vismann: Files, p. 8

20. Vismann: Files, p. 7.

21. Richard Harper: Inside the IMF. An Ethnography of Documents, Technology and Organizational Action, New York 1998, pp. 11-12.

22. Katherine Verdery: Secrets and Truth. Ethnography in the Archive of Romania's Secret Police, Budapest 2014, p. 68.

23. Angelika Menne-Haritz: Elektronische Schriftlichkeit und Geschäftsordnungen, in: Heinrich Reinermann (ed.): Neubau der Verwaltung. Informationstheoretische Realitäten und Visionen, Heidelberg 1995, p. 131, quoted in: Vismann: Files, p. 8.

24. Vismann: Files, p. 8.

25. Lüttge: Wieder gelesen, p. 178; quotes are taken from: Vismann: Files, p. xii.

26. Lüttge: Wieder gelesen, p. 179.

27. Matthew S. Hull: Government of Paper: The Materiality of Bureaucracy in Urban Pakistan, Berkeley 2012, pp. 153-160.

28. Bernhard Siegert: Passage des Digitalen. Zeichenpraktiken der neuzeitlichen Wissenschaften 1500-1900, Berlin 2003, p. 25.

29. Siegert: Passage des Digitalen, p. 63. Siegert quotes here title LXXX of the Constitutions of Frederick II for the Kingdom of Sicily »On the Execution of Charters« from Die Konstitutionen Friedrichs II von Hohenstaufen für sein Königreich Sizilien, Köln / Wien 1973, pp.122-125. 


\section{Abstract}

Files may seem an obvious topic for historians of public administration, but that is by no means self-evident. Despite the interest in files from sociologists and archival scientists in the early $20^{\text {th }}$ century, historians have engaged more with the contents of files than with their genres, materialities and functions. After tracing the theoretical and methodological engagements with files from Max Weber and Heinrich Otto Meisner to Cornelia Vismann and Bruno Latour, we argue firstly that files are defined by their relation to other records they compile. At the same time, they transmute these documents into cases and bureaucratic objects. Secondly, just as files bring documents together, they connect the activities of individuals and organizations. However, we argue that the degree to which files are instruments of formal administrative control and organizational coherence has been exaggerated, obscuring the agency of users and the potential for files to serve other ends.

\section{About the Author}

Matthew S. Hull is Associate Professor of Anthropology at the University of Michigan. His book, Government of Paper: The Materiality of Bureaucracy in Urban Pakistan, examines governance as a semiotic and material practice through an account of the role of writing and written artifacts in the operations of city government in Islamabad.

Stefan Nellen leads the Historical Analysis Services of the Swiss Federal Archives, Berne. He holds a Ph.D. in History from the University of Basel and published widely on the history of public administration and governmentality.

Thomas Rohringer wrote his PhD thesis on the development of social policy in the Cisleithanian half of Austria-Hungary and the social re-integration of disabled veterans 1880-1918 at the Technical University Berlin. He is currently holding a post-doc position at the Ludwig-Maximilians-Universität München. 